\title{
A multiplex polymerase chain reaction based method for rapid identification of two species of the genus Scolytus Geoffroy (Col: Curculionidae: Scolytinae) in Iran
}

\author{
S. Amini, R. Hosseini \\ Department of Plant Protection, University of Guilan, Rasht, Iran
}

\begin{abstract}
Molecular identification is going to be more widespread in taxonomic studies of insects when traditional tools are problematic and time consuming. Identification of bark beetles, as one of the most important pests of forests, based on morphological characteristics is difficult because of their small size and morphological similarities. In the current study, species-specific primers were desi gned to identify two most abundant and morphologically similar bark beetle species Scolytus ensifer Eichhoff 1881 and S. ecksteini Butovitsch 1929, both found on Ulmus minor Miller in north of Iran. These species-specific primers successfully produced a fragment size with 318 bp and 465 bp of mitochondrial cytochrome oxidase 1 (CO1) gene in $S$. ensifer and $S$. ecksteini respectively. The results revealed that the multiplex polymerase chain reaction using the species-specific primers could amplify a unique band to distinguish these two species so confirmed this method as a convenient and quick tool to identify those two bark beetle species.
\end{abstract}

\footnotetext{
Correspondence: Sudabe Amini, Department of Plant Protection, Faculty of Agricultural Sciences, University of Guilan, Rasht, Iran.

Tel: +98.9151602647 - Fax: +98.563242202.

E-mail: sudabe.amini@ut.ac.ir.

Key words: Bark beetle; cytochrome oxidase 1; molecular identification; multiplex polymerase chain reaction.

Acknowledgements: the authors wish to thank Sarah Smith and Anthony Cognato (United States of America, Michigan State University) for confirming morphological identification. Special thanks Dr. Arash Zibaee (University of Guilan) for theirs thoughtful comments and Hadi Sheikhnejad (University of Guilan) for technical assistance with molecular work.
}

Received for publication: 29 March 2015.

Revision received: 6 December 2015.

Accepted for publication: 7 December 2015.

(C) Copyright S. Amini and R. Hosseini, 2016

Licensee PAGEPress, Italy

Journal of Entomological and Acarological Research 2016; $48: 5181$

doi:10.4081/jear.2016.5181

This article is distributed under the terms of the Creative Commons Attribution Noncommercial License (by-nc 4.0) which permits any noncommercial use, distribution, and reproduction in any medium, provided the original author(s) and source are credited.

\section{Introduction}

Bark beetles of the subfamily Scolytinae (Coleoptera: Curculionidae) contain nearly 6000 described species worldwide by small size less than $<1 \mathrm{~mm}$ to $1 \mathrm{~cm}$ in length (Jordal, 2007). The majority of Scolytids are decomposer of plant tissues but some are aggressive pests of forests by significant economic and ecological damage in this ecosystem (Furniss \& Carolin 1977; Kuschel, 1995). The pest species of this group include those feed on phloem (true bark beetles), bore into the xylem and cultivate a fungal garden (Ambrosia beetles). Some species in the genus Scolytus Geoffroy, 1762 can transfer pathogenic ophiostomatoid fungi, which cause lethal Dutch elm disease (DED) in Ulmus (elm) trees (Gibbs, 1978). At least eight Scolytus species are known as vectors of DED including Scolytus ensifer Eichhoff, 1881 and S. pygmaeus F. 1787 (Gibbs, 1978; Faccoli et al., 1998).

Identification of bark beetles is problematic since there are paucity in morphological characteristics. Meanwhile, identification of scolytine immature stages would be more challenging if a control strategy needed to be implemented for the pest species, such as vectors of Dutch elm disease (Santini and Faccoli, 2015). S. ensifer and S. eckstei$n i$ Butovitsch, 1929 are two abundant bark beetles species in Guilan province (north of Iran) that utilize Ulmus species (Ulmaceae) (Amini et al., 2012). Traditional identification of $S$. ensifer and S. ecksteini based on morphological characteristics is difficult due to wide interand intra-specific variability of their general size, shape, and color of adults. For most Scolytus species, diagnostic characteristics are the presence and shape of spines on the abdominal sternites. In both species, location of spines on basal margin of the second abdominal sternite is identical (Pfeffer, 1994). However, shape of the spine is slightly different and taxonomic training is necessary for its correct identification (Amini \& Hosseini, 2012).

During the last decade, molecular techniques have been used for identification of insects that lack diagnostic morphological characteristics (Caterino et al., 2000) but a few molecular methods have been developed for identification of Bark beetles. Mitochondrial cytochrome oxidase I (CO1) sequences has provided tools for identification of scolytines (Stauffer et al., 1997; Kelley et al. 1999; Cognato \& Sperling, 2000; Cognato \& Sun, 2007). Johnson et al. (2008) used random amplified polymorphic DNA-polymerase chain reaction (RAPD-PCR) for identification of the two non-native bark beetles. Jordal and Kambestad (2013) used DNA Barcoding for identification of bark and ambrosia beetles. Among molecular diagnostic techniques, the multiplex PCR method uses multiple primers in a single reaction for amplification of species-specific PCR products. This method amplifies specific sequences of genome by PCR in a single reaction simultaneously to identify any life stage of numbers of species (Bej et al., 1991; Henson \& French, 1993). This method has been proven as a reliable 
identification method for economically important pests or predators (Szalanski et al., 2003; Hosseini et al., 2007; Szalanski \& McKern, 2007; Hosseini \& Hajizadeh, 2011). So, objectives of the current study were to design species-specific primers and to develop a multiplex PCR method for rapid and accurate identification of the two common Scolytus species present on Ulmus minor.

\section{Materials and methods}

\section{Bark beetle sampling}

Bark beetle specimens were collected on the trunks and twigs of $U$. minor in three different parts of Guilan province during May September 2011-2012. In total 160 samples were collected on Ulmus minor. Specimens were placed in $1.5 \mathrm{~mL}$ micro tubes, transferred to the laboratory and immediately stored at $-20^{\circ} \mathrm{C}$. All specimens were identified under a stereomicroscope (OlympusTM, model SZX-12) by using taxonomic keys (Pfeffer, 1994) and sent to Sarah Smith and Anthony Cognato (United States of America, Michigan State University) to check the identifications based on morphological characters. All voucher specimens were deposited in Natural History Museum, University of Guilan (Rasht, Iran).

\section{DNA extraction}

DNA was extracted from whole body of each identified species, separately. Each species individually was homogenized in $1.5 \mathrm{~mL}$ tubes using a sterile plastic pestle in $50 \mu \mathrm{L}$ of phosphate buffer saline $\mathrm{pH} 7.4$ Samples were incubated at $56^{\circ} \mathrm{C}$ for $4-5 \mathrm{~h}$ followed by adding $500 \mu \mathrm{L}$ of Chelex $5 \%$ (Bio-Rad Laboratories, Inc., Hercules, CA, USA), and placed in water bath at $94^{\circ} \mathrm{C}$ for $15 \mathrm{~min}$. After centrifugation at $13,000 \mathrm{~g}$ for $5 \mathrm{~min}$, DNA was transferred to a new tube and stored at $-20^{\circ} \mathrm{C}$ (Hosseini, 2010).

\section{Polymerase chain reaction and sequencing}

Three universal primers including C1-J-1718 (5'-GGAGGATTTGGAAATTGATTAGTTCC-3') as forward primer, C1-N-2191 (5'- CCCGGTAAAATTAAAATATAAACTTC -3') (Simon et al., 1994) and C1-J-2411 (5'-GCTAATCATCTAAAAACTTTAATTCCWGTWG-3') as reverse primers (Normark et al., 1999) were used to amplify a part of C01 in each species. PCR cocktails contained a total volume of $25 \mu \mathrm{L}$ including $15.05 \mu \mathrm{L} \mathrm{ddH}_{2} \mathrm{O}, 2.5 \mu \mathrm{L}$ reaction buffer, $0.25 \mu \mathrm{L}$ dNTPs $(15 \mathrm{mM}$, Fisher Scientific Inc., Hampton, New Hampshire, USA), $1 \mu \mathrm{L} \mathrm{MgCl}_{2}(50 \mathrm{mM}$ Cinnagen Co., Tehran, Iran), $1 \mu \mathrm{L}$ of each primer (forward and reverse), $10 \mu \mathrm{M}$ (Bioneer Co., Daejeon, South Korea), $0.2 \mu \mathrm{L}$ of Taq DNA polymerase ( $5 \mathrm{U} / \mu \mathrm{L}$, Cinnagen Co.) and $4 \mu \mathrm{L}$ of DNA template (50$70 \mathrm{ng} / \mu \mathrm{L})$. The master mix was placed in a $0.2 \mathrm{~mL}$ PCR tube and amplified in a thermocycler (Mastercycler gradient, Eppendorf, Germany) with the relevant temperature profile shown in Table 1. The amplified fragments were visualized by $1.4 \%$ agarose gel in TAE or TBE buffer stained in SYBER Safe DNA Gel Stain\% (Bio-Rad Laboratories, Inc.). PCR products were sequenced using the Sanger sequencing method by ABI3730XL sequence analyzer (Applied Biosystems, Foster City, CA, USA) from Bioneer Co.

\section{Sequence alignment and primer design}

C01 fragments were sequenced from three individuals per species in forward direction. Sequencing results were reviewed by the Finch Tv Soft-pedia software (http:/www.geospiza.com/ftvdlinfo.html) and edited manually for each species individually. The basic local alignment search tool (BLAST) was used to compare similarity of our nucleotide sequences with other sequences present in GenBank database, (http://www.ncbi.nlm.nih.gov/blast). Edited sequences were deposited in GenBank database with specific accession numbers (Tables 2 and 3). Sequences were aligned using MEGA ver. 5.0 software (Tamura et al., 2011) to reveal their nucleotide variation. Forward primers were designed for $S$. ensifer and $S$. ecksteini according to their sequence differences by using universal reverse primer (C1-J-2411). Guidelines proposed by Innis and Gelfand (1990) and Saiki (1990) were followed to design efficient and specific primers. The primer-primer interactions were analyzed using Integrated DNA technologies (IDT 2010; PrimerQuest: http://eu.idtdna.com/Scitools/Applications/Primer-quest/ Default.aspx) software and those were synthesized by Bioneer Co. A gradient PCR program was performed using a gradient thermocycler as 35 cycles at $94^{\circ} \mathrm{C}$ for $1 \mathrm{~min}, 50^{\circ} \mathrm{C}$ as the lower temperature and $60^{\circ} \mathrm{C}$ as the higher temperature for $45 \mathrm{~s}$, and $72^{\circ} \mathrm{C}$ for $1 \mathrm{~min} 30 \mathrm{~s}$ to optimize annealing temperature of primer pairs. A first cycle of denaturation was $94^{\circ} \mathrm{C}$ for $2 \mathrm{~min}$ and a final extension was performed at $72^{\circ} \mathrm{C}$ for $5 \mathrm{~min}$. Specificity of designed primers were evaluated using both singleplex and multiplex PCR compared with other bark beetle species including; $S$. pygmaeus (F.), S. rugulosus (Müller), Hypothenemus eruditus Westwood, and Taphrorychus lenkoranus Reitter found on other hosts in Guilan province (Amini et al., 2012).

\section{Multiplex polymerase chain reaction}

A multiplex PCR was conducted to amplify specific fragments from each bark beetle species. PCR cocktails contained a total volume of 25 $\mu \mathrm{L}$ including $4 \mu \mathrm{L}$ of DNA (20-50 ng/ $\mu \mathrm{L}), 0.25 \mu \mathrm{L}$ of dNTP's (15 mM), 1 $\mu \mathrm{L}$ of $\mathrm{MgCl}_{2}(50 \mathrm{mM}), 4 \mu \mathrm{M}$ of equal molar of each specific forward primers with one reverse universal primer (C1-J-2411) and $0.2 \mu \mathrm{L}$ of Taq DNA polymerase (5 U/ $\mu \mathrm{L})$. Cycling condition of PCR has been shown in Table 1. PCR products were mixed with loading buffer and run on $1.4 \%$ agarose gel prior to be stained by SYBER Safe DNA Gel Stain solution (Cinnagen Co.). A 100 bp DNA ladder (Fermentas, Vilnius, Lithuania) was used for determining of fragment size.

\section{Application of multiplex polymerase chain reaction}

To test efficiency of multiplex PCR for identification of the collected specimens, 70 samples of unknown adults and larvae (58 and 12

Table 1. Temperature profile for amplification of cytochrome oxidase one fragments and multiplex polymerase chain reaction.

\begin{tabular}{|c|c|c|c|c|c|}
\hline \multicolumn{2}{|r|}{ C1-J-1718/ C1-J-2411 } & \multicolumn{2}{|c|}{ C1-J-1718/ C1-N-2191 } & \multicolumn{2}{|r|}{ Multiplex PCR } \\
\hline 1 & $94^{\circ} \mathrm{C}$ for $2 \mathrm{~min}$ & 1 & $94^{\circ} \mathrm{C}$ for $2 \mathrm{~min}$ & 1 & $94^{\circ} \mathrm{C}$ for $2 \mathrm{~min}$ \\
\hline 2 & $94^{\circ} \mathrm{C}$ for 1 min & 2 & $94^{\circ} \mathrm{C}$ for $1 \mathrm{~min}$ & 2 & $94^{\circ} \mathrm{C}$ for $1 \mathrm{~min}$ \\
\hline 3 & $52^{\circ} \mathrm{C}$ for $45 \mathrm{~s}$ & 3 & $50^{\circ} \mathrm{C}$ for $1 \mathrm{~min}$ & 3 & $53^{\circ} \mathrm{C}$ for $1 \mathrm{~min}$ \\
\hline 4 & $72^{\circ} \mathrm{C}$ for $1 \mathrm{~min}$ & 4 & $72^{\circ} \mathrm{C}$ for $1 \mathrm{~min}$ & 4 & $72^{\circ} \mathrm{C}$ for $1 \min 30 \mathrm{~s}$ \\
\hline 5 & Go to 2 for 34 cycle & 5 & Go to 2 for 34 cycle & 5 & Go to 2 for 35 cycle \\
\hline 6 & $72^{\circ} \mathrm{C}$ for $5 \mathrm{~min}$ & 6 & $72^{\circ} \mathrm{C}$ for $5 \mathrm{~min}$ & 6 & $72^{\circ} \mathrm{C}$ for 5 min \\
\hline
\end{tabular}


respectively) were collected on $U$. minor from different locations of Guilan province and identified morphologically by expert entomologist (Sarah M. Smith Ph.D. in Michigan State University). Four adults and two larvae were selected for the multiplex PCR test. All specimens were individually placed in $1.5 \mathrm{~mL}$ tubes and kept at $-20^{\circ} \mathrm{C}$ for subsequent molecular assay. DNA extractions were performed using the Chelex 5\% (Bio-Rad Laboratories, Inc.) method described earlier.

\section{Results}

In this study, adults of three Scolytus species including S. ecksteini, $S$. ensifer, and $S$. pygmaeus were identified morphologically and a part of their $\mathrm{C} 01$ was successfully amplified. The universal primers, C1-J1718/ C1-J-2411, amplified fragments of approximately 650 bp of $C O 1$ gene in $S$. ecksteini, $S$. pygmaeus and $S$. rugulosus, but amplification was not successful for $S$. ensifer. Therefore primers C1-J-1718/ C1-N2191 were used to amplify a shorter fragment in $S$. ensifer. These universal primers amplified first 465 bp of $\mathrm{C01}$ upstream region in $S$. ensifer but those amplified nearly 650 bp barcode region in other
Scolytus species (Hebert et al., 2003). Amplified fragments varied in size because of using different primers. Size of fragments was 610 , 650,661 and 465 bp in Scolytus rugulosus, S. pygmaeus, S. ecksteini and S. ensifer, respectively.

BLAST searches on Genbank show high similarity to others Scolytus species. Obtained sequences were submitted to Genbank and were provide accession number (Table 2 ).

Three equal molar primers including two specific forward primers and one universal reverse primer (C1-N-2191) were combined in a multiplex PCR assay to achieve a quick and robust molecular technique for identification two species of bark beetles on Ulmus trees in Guilan province. The optimal annealing temperature for multiplex PCR was determined to be $53^{\circ} \mathrm{C}$. Results indicated that the specific used primers developed were successfully amplified the expected specific fragment for $S$. ensifer and S. ecksteini. The size of PCR products for S. ensifer and S. ecksteini were 318 bp and 465 bp respectively. Specificity tests for primer pairs showed amplification of fragments for target species although no amplification was observed in $S$. pygmaeus and $S$. rugulosus as non-target species (Figure 1). Our results also verified the application of multiplex PCR for successful identification of field-collected specimens (Figure 2).

Table 2. Species, primers and GenBank accession numbers for mitochondrial cytochrome oxidase one sequences.

\begin{tabular}{lcc} 
Species & Primers & Accession numbers \\
Scolytus ensifer & $(1718 / 2191)$ & JX913804 \\
Scolytus ecksteini & $(1718 / 2411)$ & JX416909, JX416907, JX416902 \\
\hline Scolytus pygmaeus & $(1718 / 2411)$ & JX089346, JX089347, JX089348 \\
Scolytus rugulosus & $(1718 / 2411)$ & JX089345, JX089343, JX089342 \\
\hline Scolytus pygmaeus & $(1718 / 2411)$ & JX089346, JX089347, JX089348 \\
\hline
\end{tabular}

Table 3. Species-specific forward primers for cytochrome oxidase one, length of primer and fragment size.

\begin{tabular}{lcccc} 
Species & Primer name & Primer sequence $\left(5^{\prime}\right.$ to $\left.3^{\prime}\right)$ & Primer length (bp) & Fragment sive (bp) \\
Scolytus ecksteini & EC-S19 & GATTTCCTCTATTTGGTGCTA & 22 & 465 \\
Scolytus ensifer & EN-S20 & TTTACTCTCGTTGCCCTAC & 20 & 318 \\
\hline
\end{tabular}

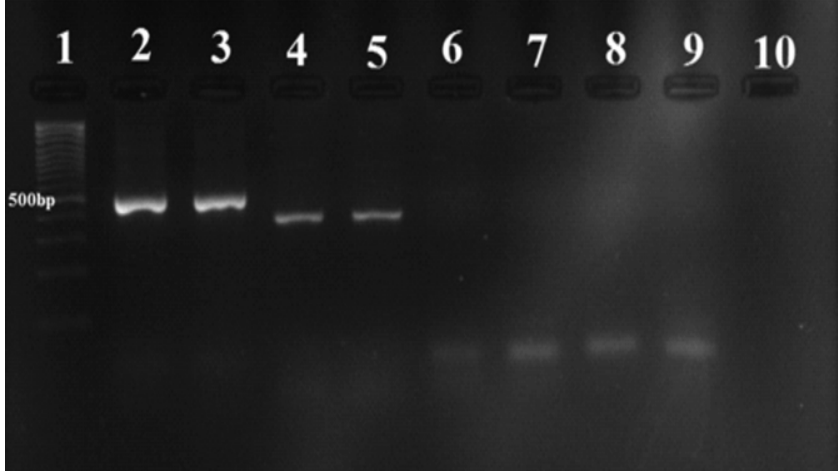

Figure 1. Multiplex polymerase chain reaction by combination of three equimolar primers for CO1. 1: 100 bp DNA ladder; 2 and 3: Scolytus ecksteini; 4-5: S. ensifer; 6: S. pygmaeus; 7: S. rugulosus; 8: Hypothenemus eruditus; 9: Taphrorychus lenkoranus; 10: negative control.

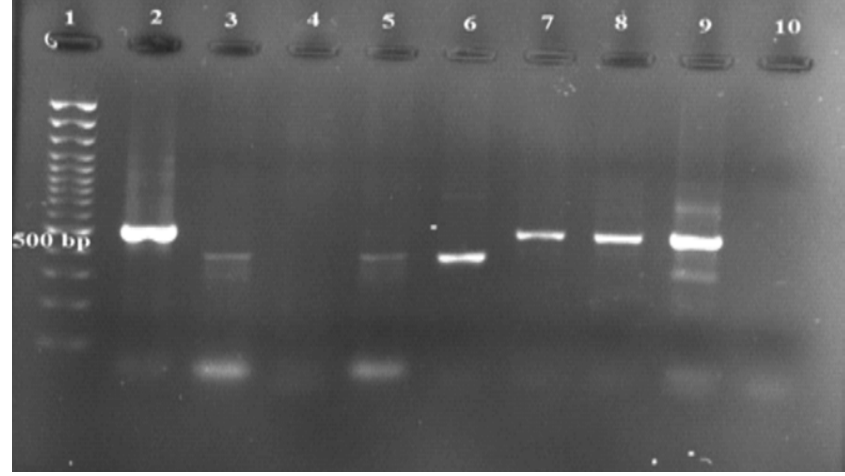

Figure 2. Multiplex polymerase chain reaction test for identification of field collected specimens. 1: 100 bp DNA ladder; 2 and 3: positive control (Scolytus ensifer and S. ecksteini); 4: unknown species larvae; 5-6: $S$. ensifer adults; 7-8: $S$. ecksteini adults; 9: $S$. ecksteini larvae; 10: negative control. 


\section{Discussion and conclusions}

Accurate identification of pests is fundamental in control strategy of them. In this study in the first step part of mitochondrial genome sequenced successfully and then designed primers and test primers to amplify specific fragments. The major problem in identification of bark beetles species is similarity of morphological characters such as similarity in shape of spine that is exactly on the same sternites of abdomen in both species (Amini et al., 2012) that makes identification difficult, time consuming, and morphologic method needs good quality specimens and expertise in specialized taxonomy (Leclercq \& Lecomte, 1978). Above all Scolytus species are vectors of fungi Ophostomaid ulmi that lead to Dutch elm disease and implementation of a specific control strategy for species would be a crucial challenge if identification should be made in their immature stages. According to recent studies PCRbased methods have shown to be a powerful tool in the identification of quarantined pests that have a similar morphology (Hosseini et al., 2007), but the molecular technology using mtDNA is easier to perform and saves time. This method can also identify damaged specimens with lack of morphological characters (Judith \& Nicola, 2008).

As Bark beetles life cycle is under the bark of tree, in most of time they are not accessible in numerous and just their galleries or their vouchers are represented. So multiplex-PCR method could be an efficient identification tool when a specimen is one of only a handful of species (Gariepy et al., 2008). Results of this study indicated that different Scolytus species could utilize and simultaneously live on the same branches of elm trees. Those are very similar so their discrimination might be difficult mainly in immature stages. A rapid identification method develop for diagnosis of two important similar species of bark beetles among the bark beetles that attack elm trees.

Our experiments confirmed efficiency of multiplex PCR method for identification of field collected Scolytus in both larval and adult stages in same time that might be compared with findings of Hosseini et al. (2007) and Hosseini and Hajizadeh (2011). Hosseini and Hajizadeh (2011) designed species-specific primer and identified three mealybug species belong to different geographic location in a single reaction by multiplex PCR.

In this study C01 in mtDNA region is selected for design of primers, because studies have shown that this region is useful for identification of Coleoptera species (Paul et al., 2009; Dirk et al., 2007; Fang, 2009) as result showed high potential of this region of genome in discrimination of Scolytus species.

Johnson et al. (2008) developed a RAPD-PCR method to identify collected Scolytus species as the two non-native bark beetles. Although, the authors insist on using selected oligonucleotide primers in the RAPD-PCR analysis but other studies showed RAPD-PCR technique as a notoriously laboratory-dependent that could not be reproducible in other conditions (Johnson et al., 2008). Our study, the specific primers were successfully designed according differentiates in sequences and developed from Barcoding region of $S$. ensifer and S. ecksteini species (C01, 5' upstream region) and distinguished species from the other scolytid species accurate, in one reaction simultaneously.

Chen et al. (2013) designed species-specific primers according to C01 region of an invasive species Dendroctonus valens Leconte by using Nested PCR method. The authors had chosen the specific region of genome by Nested PCR method to design the high sensitive and specific primers for rapid and accurate distinguish beetles from the others that are abundant in China ports. Chen et al. (2013) result is compared with our essay, but because in $S$. ensifer species PCR was not successful and DNA could not amplified by universal primers, this led to choose a shorter region of $\mathrm{CO}$ genome to amplify. Combination of the two specific primers along with a reverse primer could successfully generated two identical different fragments, which is a major necessity in designing multiplex PCR primers. The species-specific associated primers could be successfully used in multiplex PCR to amplify products with two different sizes, which allows identification of the two bark beetle species in a single reaction. It is possible to identify a large number of Scolytus species even in immature developmental stages, which might be a rapid and relatively low cost. This method proved to be an applicable technique for forestry studies, which is rapid and accurate particularly when the issue involves quarantine pests. Multiplex PCR has ability to detect detecting pathogens in insect vectors (Roy et al., 2005; Ravikumar et al., 2011) like ambrosia beetles and it would be applicable in future study to detect fungi transported by ambrosia beetle by this innovative methods.

\section{References}

AMINI S., HOSSEINI R., 2012 - Introduction and identification key for three elm bark beetles species in central part of Guilan province. Plant Pests Res. 2:13-20 [In Persian].

AMINI S., HOSSEINI R., SOHANI M., 2012 - A faunal study of Bark beetles (Coleoptera: Curculionidae: Scolytinae) in Guilan province in North of Iran. - Entomofauna. 12: 169-176.

BEJ A.K., MCCARTY S.C., ATLAS R.M., 1991 - Detection of coliform bacteria and Escherichia coli by multiplex polymerase chain reaction, comparison with defined substrate and plating methods for water quality monitoring. - App. Environ. Microbiol. 57: 2429-2432.

CATERINO M.S., CHO S., SPERLING F.A.H., 2000 - The current state of insect molecular systematics: a thriving tower of babel. - Ann. Rev. Entomol. 45: 1-54.

CHEN F., LUO Y., LI J. G., ZHAO H., ZONG SH., SHI J., 2013 - Rapid detection of red turpentine beetle (Dendroctonus valens Leconte) using nested PCR. - Entomol. Am. 119: 7-13.

COGNATO A.I., SPERLING F.A.H., 2000 - Phylogeny of Ips DeGeer species (Coleoptera: Scolytidae) inferred from mitochondrial cytochrome oxidase I DNA sequences. - Mol. Phyl. Evol. 14: 445-460.

COGNATO A.I., SUN J.H., 2007 - DNA based cladograms augment the discovery of a new Ips species from China (Coleoptera: Curculionidae: Scolytinae). - Cladistics. 23: 539-551.

DIRK A., MICHAEL T.M., ALFRIED P.V., 2007 - DNA-based taxonomy for associating adults and larvae in multi-species assemblages of chafers (Coleoptera: Scarabaeidae). - Mol. Phyl. Evol. 44: 436-449.

FACCOLI M., ZANOCCO D., BATTISTI A., MASUTTI L., 1998 - Chiave semplificata per la determinazione degli Scolytus Geoffroy (Coleoptera: Scolytidae) Italiani viventi sugli olmi. - Redia 81: 183-197.

FANG X.M., 2009 - Phylogenetic analysis of Chrysomelidae in China inferred from mitochondrial C01 sequences (Coleoptera: Chrysomeloidea). - J. Suzhou. Univ. 24: 113-117.

FURNISS R.L., CAROLIN V.M., 1977 - Western forest insects. - United States Department of Agriculture, Forest Service; miscellaneous publication 1339: 1-654.

GARIEPY T.D., KUHLMANN U., HAYE T., GILLOTT C., ERLANDSON M., 2008 - A single-step multiplex PCR assay for the detection of European Peristenus spp., parasitoids of Lygus spp. - Biocontrol. Sci. Techn. 15: 481-495.

GIBBS J.N., 1978 - Intercontinental epidemiology of Dutch elm disease. - Ann. Rev. Phytophathol. 16: 287-307.

HEBERT P.D.N., CYWINSKA A., BALL S.L., DE WAARD J.R., 2003 Biological identification through DNA barcodes. - Proc. R. Soc. B Biol. Sci. 270: 313-321.

HENSON J.M., FRENCH R., 1993 - The polymerase chain reaction and plant disease diagnosis. - Ann. Rev. Phytopathol. 31: 81-109

HOSSEINI R., 2010 - An introduction to the principle of molecular biology techniques (With emphasizing on the study of insects). University of Guilan Press. 232pp (In Persian). 
HOSSEINI R, HAJIZADEH J., 2011 - Molecular identification of three of the most important mealybug species (Hemiptera: Sternorrhyncha: Coccoidea: Pseudococcidae) on ornamental plants in Guilan province, Iran. - Zootaxa 2009: 46-54.

HOSSEINI R., KELLER M.K., SCHMIDT 0., FRAMENAU V.W., 2007 Molecular identification of wolf spiders (Araneae: Lycosidae) by multiplex polymerase chain reaction. - Biol. Control 40: 128-135.

INNIS M.A, GELFAND D.H., 1990 - Optimization of PCRs. In: GELFAND D.H., SNINSKY J.J., INNIS M.A., WHITE H., Eds., PCR protocols: a guide to methods and applications. - Academic Press, San Diego, CA: 3-12.

JOHNSON P., HAYES J. L., RINEHART J., SHEPPARD W.S., SMITH S.E., 2008 - Characterization of two non-native invasive bark beetles, Scolytus schevyrewi and Scolytus multistriatus (Coleoptera: Curculionidae: Scolytinae). - Can. Entomol. 140: 527-538.

JORDAL B.H., 2007 - Reconstructing the phylogeny of Scolytinae and close allies: major obstacles and prospects for a solution. - USDA Forest Service Proceedings RMRS 45: 3-8.

JORDAL B.H., KAMBESTAD M., 2013 - DNA barcoding of bark and ambrosia beetles reveals excessive NUMTs and consistent eastwest divergence across Palearctic forests. - Mol. Ecol. Res. 14: 7-14.

JUDITH A.S., NICOLA C.B., 2008 - Molecular genetic identification of forensically important flies in the UK. - For. Sci. Int. Genet. Suppl. Ser. 1: $620-622$.

KELLEY S.T., MITTON J.B., PAINE T.D., 1999 - Strong differentiation in mitochondrial DNA of Dendroctonus brevicomis (Coleoptera: Scolytidae) on different subspecies of Ponderosa pine. - Ann. Entomol. Soc. Am. 92: 193-197.

KUSCHEL G., 1995 - A phylogenetic classification of Curculionoidea to families and subfamilies. - Entomol. Soc. Wash. 14: 5-33.

LECLERCQ M., LECOMTE J., 1978 - Emergency treatment of insect bite complications. - Rev. Méd. Liège 33: 240-249.

NORMARK B.B., JORDAL B.H., FARRELL B.D., 1999 - Origin of a haplodiploid beetle lineage. - Proc. Royal Soc., Lon. Ser. B 266: 2253-2259.

PAUL F., RUGMAN J., ROBERT W., TOM V.N., RICHARD S., 2009 Molecular differentiation of the Psyttalia concolor (Szépligeti) species complex (Hymenoptera: Braconidae) associated with olive fly, Bactrocera oleae (Rossi) (Diptera: Tephritidae), in Africa. Biol. Control. 49: 17-26.

PFEFFER A., 1994 - Zentral- und westpaläarktische Borken- und Kernkäfer (Coleoptera: Scolytidae: Platypodidae). - Entomol. Basil. 17:5-310.

RAVIKUMAR G., RAJE URS S., VIJAYA PRAKASH N.B., RAO C.G.P., VARDHANA K.V., 2011 - Development of a multiplex polymerase chain reaction for the simultaneous detection of microsporidians, nucleopolyhedrovirus, and densovirus infecting silkworms. - J. Invertebr. Pathol. 107: 193-197.

ROY A., FAYAD A., BARTHE G., BRLANSKY R.H., 2005 - A multiplex polymerase chain reaction method for reliable, sensitive and simultaneous detection of multiple viruses in citrus trees. - J. Virol. Methods. 129: 47-55.

SAIKI R.K., 1990 - Amplification of genomic DNA. In: INNIS M.A., GELFAND D.H., SNINSKI J.J., WHITE T.J., eds., PCR protocols: a guide to methods and applications. - Academic Press, San Diego, CA: $13-20$.

SANTINI A., FACCOLI M., 2015 - Dutch elm disease and elm bark beetles: a century of association. iForest. 8: 126-134.

SIMON C., FRATI F., BECKENBACH A., CRESPI B., LIU H., FLOOK P., 1994 - Evolution, weighting, and phylogenetic utility of mitochondrial gene sequences and a compilation of conserved polymerase chain reaction primers. - Ann. Entomol. Soc. Am. 87: 651-701.

STAUFFER C., LAKATOS F., HEWITT G.M., 1997 - The phylogenetic relationships of seven European Ips (Scolytidae, Ipinae) species. - Ins. Mol. Biol. 6:233-240.

SZALANSKI A.L., AUSTIN J.W, OWENS C.B., 2003 - Identification of Reticulitermes spp. (Isoptera: Rhinotermitidae) from the South Central United States by PCR-RFLP. - J. Eco. Entomol. 96: 1514-1519.

SZALANSKI A.L., MCKERN J.A., 2007 - Multiplex PCR-RFLP diagnostics of the Africanized honey bee (Hymenoptera: Apidae). Sociobiology. 50: 939-945.

TAMURA K., PETERSON D., PETERSON N., STECHER G, NEI M., KUMAR S., 2011 - MEGA5: molecular evolutionary genetics analysis using maximum likelihood, evolutionary distance, and maximum parsimony methods. - Mol. Biol. Evol. 28: 2731-2739. 